\title{
Pre-conception Nutrition Care, Nutritional Knowledge, Nutritional Practices, and Cultural Belief Among Pregnant Women: A Qualitative Study in Aceh
}

\author{
${ }^{1}$ Aripin Ahmad, ${ }^{1}$ Silvia Wagustina, ${ }^{2}$ Wiwit Estuti, ${ }^{3}$ Syuja' Rafiqi Arifin \\ ${ }^{1}$ Departement of nutrition, Health Polytechnic of Aceh, Banda Aceh, Indonesia, 23238, Indonesia \\ ${ }^{2}$ Departement of nutrition, and Center of Excellent for Health and Disaster Emergency (HaDE), Health \\ Polytechnic, Tasikmalaya, Cirebon, Indonesia, 46115, Indonesia \\ ${ }^{3}$ Nutrition Study Program, Health Science Faculty, Alma Ata University, Yogyakarta, Indonesia, 55183, \\ Indonesia \\ Coresponding author: Aripin Ahmad, aripinahmad@poltekkesaceh.ac.id
}

\section{ABSTRACT}

Health care during pre-conception and pregnancy is one of the important factors that can improve pregnancy outcomes. This study aims to explore how pre-conception care, nutrition knowledge and practices, and the factors that influence it in pregnant women. This study used a cross-sectional design with a qualitative study approach. The subject was 11 pregnant women who were selected as well as 5 health workers. The data pre-conception of care and nutrition practices before pregnant, nutrition knowledge and nutrition practices, food taboo and suggestion, cultural belief influence, and data sources of information and nutritional information needs was carried out using the Focus Group Discussion. The results showed that most of the pregnant women did not get and done pre-conception nutrition care, had insufficient nutritional knowledge and the practice of balanced nutrition was still low. There is still an influence of cultural belief in the form of food taboos and food suggestions, and the lack of sources of information and nutritional information towards nutrition practice. It is necessary to develop media and nutrition educational methods to improve nutrition and health care during pre-conception and pregnancy, and further studies are needed specifically on the role of family factors, especially grandmothers, mothers in-laws, and family members on nutrition practices in pregnant women.
\end{abstract}

\section{ARTICLE INFORMATION}

Submitted: $09 / 11 / 2020$

Revised: $17 / 11 / 2020$

Accepted: $28 / 11 / 2020$

Published Online: 30/11/2020

Keywords:

Cultural belief

Maternal knowledge

nutritional practices

pre-conception

pregnant women

How to cite this article: Ahmad, A., Wagustina, S., Estuti, W., Arifin, S. R. (2020). Pre-conception Nutrition Care, Nutritional Knowledge, Nutritional Practices, and cultural Belief among pregnant women: A Qualitative Study in Aceh. JNS : Journal of Nutrition Science, 1(2), 13-26.

\section{Introduction}

Malnutrition in the first 1000 days of life, especially during pregnancy, affects the growth and development of the infant (AbuSaad, 2010). Several nutritional problems that remain a problem in Indonesia are the high prevalence of pregnant women suffering from chronic energy deficiency (CED) and anemia. Basic Health Research (2018) shows one in five pregnant women suffer from chronic energy deficiency and $48.9 \%$ of pregnant women suffer from anemia in
Indonesia. In Aceh, $12.3 \%$ of pregnant women suffered from CED and $46 \%$ suffer from anemia (Ministry of Health, 2018).

The high prevalence rate of CED and anemia in pregnant women is related to inappropriate nutrition practices, referring to the guidelines for balanced nutrition, there are ten nutrition practices that mothers must do during pregnancy, namely; consume three servings of carbohydrate sources, consume three servings of animal side dishes, three servings of vegetable side dishes, three 
servings of vegetables, three servings of fruits, consume two additional meals to meet energy needs and additional nutrients, consume 1 iron tablet a day, drink Sufficient water is at least eight glasses, implement a clean and healthy lifestyle, including washing hands with soap, and doing physical activity for at least 30 minutes every day (Ministry of Health, 2020). The application of the ten messages of balanced nutrition during pregnancy will ensure the fulfillment of energy and nutrient needs and avoid anemia and have a body that is fit and free from infection and disease.

Several studies have shown that the practice of balanced nutrition among pregnant women in Indonesia is still low, this is indicated by the low intake of energy and nutrients and low compliance of mothers in consuming the iron tablet. Data Indonesian Survey of Food Consumption in 2014 showed $49.6 \%$ of pregnant women in urban areas and $55.7 \%$ in rural areas have protein intake $<80 \%$ RDA (Ministry of Health, 2014). The compliance of pregnant women consumed iron tablets of 90 tablets or more is still low, only $33.3 \%$ in 2013 and $38.1 \%$ in 2018 (Ministry of Health, 2013, Ministry of Health, 2018). Other studies on 203 pregnant women in Bogor showed more than $50 \%$ of pregnant women have inadequate intake of iron, zinc, calcium, vitamin A and vitamin C (Madanidjah et al. 2016).

Fulfillment of nutritional needs is one aspect important during pregnancy, according to the principle of nutrition during pregnancy, the nutritional intake of the mother should be able to meet the needs of mothers and needs of the fetus, so it takes the quality and amount of energy and nutrients balanced, fairly and have high bioavailability. For that, we need a good dietary pattern for pregnant women. Knowledge, attitudes, motivation, and factors related to health services such as nutrition education and the family environment, as well as the existing socioculture in the community will affect the nutritional behavior practiced by pregnant women.

Information on a scientific nature through a special study of the factors that influence the nutritional behavior of pregnant women in Aceh is still limited, therefore this study aims to explore Pre-conception care and nutrition practices before pregnant, nutrition knowledge and nutrition practices, food taboo and suggestion, cultural belief influence, and data sources of information and nutritional information needs.

\section{Method}

This study used a cross-sectional design with a qualitative study method to determine nutrition practices in pregnant women and the factors that influence it in the work area of the Darul Imarah Community Health Center, Aceh Besar District. The research sample was 11 pregnant women who were selected based on the inclusion criteria: $1)$. Pregnant women $1^{\text {st }}-3^{\text {rd }}$ trimester. Do not experience pregnancy complications (sick conditions or pregnancy disorders), 3). Willing to take part in research, as well as 5 health workers (nutrition workers and village midwives) who are responsible for the nutrition and maternal and child health program. The data collected includes; Preconception care and nutrition practices before pregnant, nutrition knowledge and nutrition practices, food taboo and suggestion, cultural belief influence, and data sources of information and nutritional information needs. Data collection was carried out using the Focus Group Discussion (FGD) method with stages, opening, clarifying, reflecting, motivating, digging for deeper information, blocking and distributing to provide opportunities for all respondents to provide information/voice, reframing, focus, break up the debate. if any and take advantage of the time lag and close the FDG. To facilitate the implementation of FGDs, the FGD guidelines are used, namely the FGD guidelines for pregnant women and staff who have been prepared according to the research objectives.

Data FGD results processing was carried out in six stages, namely 1 ). listen to the FGD recordings, 2). Making a transcript, 3). Rereading the transcript, 4$)$. Determine the prominent and recurring topics that appear in the transcript, 5). Data grouping based on data classification (consensus, differences of opinion, different experiences, and specific or innovative opinions that emerged, 6) coded information. Furthermore, data analysis is carried out using the thematic analysis method carried out in 7 stages, namely 
recording all information systematically, making data outlines, comparisons and grouping data outlines, building themes and codes, building evaluations, interpreting results, and conclusions. Ethical Approval of this study has been received from The Ethical Committee of Health Polytechnic of Aceh with number LB.02.03/7144/2019.

\section{Results}

Focus group discussions (FGD) aimed to find nutritional practices, implementers of appropriate nutrition, and factors affecting maternal nutritional practices in the application during pregnancy. The FGD targets were 11 pregnant women and 5 health workers (nutrition workers and midwives) in charge of the nutrition and mother and child health program from the work area of the Darul Imarah community health center Aceh Besar District.

\section{Pre-conception care and nutrition practices before pregnant}

In general, pregnant women do not prepare specifically related to nutritional aspects before pregnancy (pre-pregnancy), some of the actions taken by pregnant women before becoming pregnant are increasing consumption of vegetables such as bean sprouts to increase fertility, some women do not do food consumption patterns. Specifically, namely consuming food such as normal days and what is available at home, some respondents stated that they had checked with a doctor, while the food was related to what was suggested by the doctor as stated by the respondent in box 1 below:

Box 1.

Mrs. S " Nothing sir, just eat what is there" $\mathrm{Bu} \mathrm{H}$ "What's in the house too Sir, there is no special meal. Most people say, made to eat bean sprout".

Mrs. N "Yes, me too sir, have to eat bean sprouts"

Mrs. M "If I'm not there sir, what's in my house will eat "

Mrs. $\mathrm{F}$ "If I go to the doctor at most and it depends on what the doctor recommends "

Meanwhile, related to the early examination of the nutritional condition of the mother before pregnancy, no mother who checked before becoming pregnant, the examination of the state of nutrition was only carried out after it was found out that some of the women were pregnant, while some of the others if there were any visits to the officer or doctor, almost all of the respondents stated that they were not. know how to find out the condition of the mother's nutrition before pregnancy, as well as the practice of checking hemoglobin to find out anemia, most women stated that they had never checked before becoming pregnant and only did the examination after pregnancy (Box 2).

Box 2.

Mrs. A. " No sir, usually after pregnancy we check it "

Mrs. S. "I don't know sir"

Mrs. M. "I don't know either sir"

Mrs. A. " At most check with the doctor sir "

The results showed that although pregnant women did not carry out $\mathrm{Hb}$ checks before pregnancy, some of them knew the signs of anemia, including dizziness, pallor, lethargy, pale/white eyelids, nausea, numbness, lack of desire, however, some pregnant women who identify signs of anemia with signs or symptoms of hypotension such as headaches and low blood pressure (Box 3 ).

Mrs. $M$ "Dizziness, center, lethargy"

Mrs. A "Dizzy, not the spirit of the person" Mrs. F. "Dizzy, pale sir"

Mrs. Y. " In my opinion, sir, if his eyelids are white it means he is less bloodied"

Mrs. E. "Dizziness, nausea sir"

Mrs. F. "Numb sir"

Mrs. H. "Lack of passion sir"

Mrs. S. "Headache sir"

The results of the study related to the knowledge of mothers about the conditions of mothers at risk of becoming pregnant, based on the results of the FGD, showed that mothers at risk of becoming pregnant according to the knowledge of pregnant women were elderly, diabetics, myoma, acid reflux disease, hypertension and mothers with poor nutritional conditions (Box 4).

Box 4.

Mrs. $H$ "The elderly and there are diabetics 
Sir "

Mrs. E "There is a regular myoma sir"

Mrs. $F$ "There is a disturbance with the stomach sir"

Mrs. $F$ " The one with high blood, Sir "

Mrs. $N$ "The one who is malnourished sir "

Most pregnant women do not know how to assess whether a mother is malnourished or not, but generally, they know the impact of malnutrition on the mother and her fetus, among other things, effects are; the mother loses weight and is harmful to the fetus (Box $5)$.

Box 5

$\mathrm{Bu} Y$ "If the mother is pregnant and doesn't eat, then she will get sick so she will lose weight. So the risk to the baby ".

Mrs.E " The danger to the fetus, Sir. Usually pregnant people find it difficult to eat, so they will lack nutrition ".

\section{Nutrition knowledge and nutrition practices}

The results showed that pregnant women did not know for sure about weight gain during pregnancy, some mothers said that between $2-3 \mathrm{~kg}$ and between $3-4 \mathrm{~kg}$ (Box $6)$.

\section{Box 6}

Mrs. E " About $2 \mathrm{~kg} \mathrm{Sir"}$

$\mathrm{Bu} H$ "Usually according to our diet and body weight. For example, a bodyweight of $48 \mathrm{~kg}$, you will increase 2 to $3 \mathrm{~kg}$ "

Mrs. $S$ "some are $3 \mathrm{~kg}$, some are $4 \mathrm{k}$, Sir, depending on how much we eat "

The results showed that generally pregnant women did not understand in detail balanced nutrition for pregnant women, overall in daily food consumption, pregnant women had mentioned the types of food ingredients, including balanced nutrition, which was consuming foods with vegetables and fruit sources, carbohydrate sources such as rice, Animal side dishes such as meat, eggs and milk, fish and foods that are 4 healthy 5 perfect, meaning that the understanding of pregnant women about balanced nutrition still refers to the 4 healthy 5 perfect diets (Box 7).

\section{Box 7}

Mrs. E "I don't know sir. But at first glance, balanced nutrition is like there are vegetables and fruits. Then there are carbohydrates sir" $B u$ E Yes, there is rice, there is meat, vegetables, there are eggs and milk. That's it sir

$\mathrm{Bu} Y$ "Likewise sir, there are vegetables, fruits, milk"

$\mathrm{Bu} M$ " Rice, vegetables, fruit, fish, there is also meat sir"

Bu A "I don't like vegetables, Sir. So most eat fruit sir

Mrs. A " 4 healthy 5 perfect "

Mrs. $S$ " Eat a little, with small portions. There are vegetables, fruits, milk and you should drink lots of water. That's all sir"

Mrs. A "Same too, Sir. There are rice, fruits, vegetable, and milk"

Regarding the frequency of eating for pregnant women, it is recommended that between 3 to 5 times and some mothers stated that it depends on the presence of hunger, and it is generally uncertain, besides eating staples it is also interspersed with snacks (Box 8).

\section{Box 8.}

Mrs. $H$ " 3 times a day, sometimes more than 3 and 5 times "

Mrs. E "It depends on how hungry you are, sir. But it should be 3 times, just have to be on time and interspersed with other snacks".

Mrs. M " 3 times Sir. But sometimes 2 times sir"

The application of a diet based on the contents of the recommended dinner plate during pregnancy shows that most of the respondents stated that each meal consisted of vegetables, vegetable side dishes, animal side dishes, but some respondents stated that not every meal consisted of various types of food sources, sometimes -sometimes just enough with rice and fish which is important a large amount of food (Box 9). 
Box 9.

Bu $F$ "Vegetables, eggs, tofu, tempeh, there are also meat and rice sir"

Mrs. S "For me, sir, if you have side dishes, you will have enough rice and vegetables, Sir. Sometimes I want to eat, sometimes I don't eat too, Sir "

Mrs. $H$ "If I am different again, Sir. If you have rice and salted fish, that's enough. The important thing is to eat a lot and what is there ".

The results showed that pregnant women already knew examples of carbohydrate source foods, several types of carbohydrate source foods mentioned were rice, bread, wheat, sweet potatoes, tubers, and cereals (Box 10).

Bu E " Rice, bread, wheat "

Box 10.

Bu Y "Rice, bread, wheat "

Bu Fd" Rice, bread, wheat, sweet potatoes, tubers"

Bu Ft" Rice, cereal "

Bu A "I don't have an appetite for rice. So like to eat bread ".

Mrs. M" Rice, wheat"

While the types of food sources of animal protein (animal side dishes) mentioned include fish, meat, eggs. However, some respondents did not know. (Box 11).

Bu Fd " Fish, meat, eggs "

Box 11.

Mrs. S "I don't know sir"

Mrs. A "Don't know Pa k"

Meanwhile, for food sources of vitamin A, generally, the respondents did not know, only one mother mentioned sweet potato as a source of vitamin $A$, other than that she did not know (Box 12).

Mrs. N "I don't know sir"

Box 12.

Bu E "Sweet Potatoes "

Bu Fd "I don't know sir"

Mrs. M "I don't know either sir"

Furthermore, food sources of iron generally mention cassava leaves, spinach, corn broccoli, meaning that pregnant women only mention sources of iron from plant-based foods from the vegetable group, while no one knows the source of iron from animal foods (Box 13).

\section{Pregnant women "Sweet potato} cassava leaves, spinach, broccoli ".

Box 13. Mrs. Y" Corn "

Supplementary food during pregnancy, the results of research that explores the practice of mothers consuming additional food and the importance of supplemental food during pregnancy show that most pregnant women consume additional food besides the main food, the form of additional food consumed is in the form of snacks and fruits, peanut porridge. green beans, red bean porridge, bread and biscuits, and additional food sources purchased or made by yourself. The reason the respondents consume additional food is so that the mother and fetus are healthy. (Box 14).

\section{Mothers: Yes}

Box 14.

Bu Y " Snack, fruits "

Mrs. E " Most porridge, sir"

$\mathrm{Bu} H$ "Yes, green bean porridge, sir. Red Bean"

Mrs. N" Once, bread and biscuits sir "

Bu A " Roti Pak"

Mothers: Buy yourself Sir, who is for Sir

Mrs. S "extra food so that mother and baby are healthy"

The result of this study showed that most respondents already knew the importance of consuming blood-supplemented tablets, all respondents stated that iron supplemented tablets were obtained from Puskesmas. Some reasons pregnant women need to consume iron tablets by respondents are, to prevent the risk of bleeding during childbirth so that when giving birth there is enough blood so that there is no need for donors, so that pregnant women have strong energy during childbirth, but some of the perceptions of mothers about lack of hemoglobin were determined by blood pressure measurement (Box 15). 
Mothers "Yes Sir"

Box 15.

Mothers "From the Puskesmas Sir"

Bu Fida: So that there is no risk of bleeding during delivery, Sir

Bu Hus: To be strong during childbirth

Mrs. Eli: Even at delivery, you don't need to get the blood

Mrs. Fitri: To be strong Sir

Bu Atun: During my pregnancy, I often lacked blood, Sir

Bu Murni: Let me stop the bleeding during childbirth Sir

Respondents know the importance of consuming iron tablets, but compliance with the practice of consuming iron tablets is still low. The results of this study indicate that not all pregnant women are obedient to consuming it every day. Respondents stated that they consume iron tablets with an uncertain consumption frequency, some mothers consume it every day, some say they rarely consume it due to forgetfulness, fear of excess, after drinking headaches. However, some respondents stated that they regularly consume it every day and there is no impact (Box 16).

Mrs. E " Not sure sir, sometimes forget "

Bu Y "Yes, I am every day sir"

Mrs. Fd "For only 1 month, Sir, because it's only the first trimester "

Mrs. F $t$ "If I rarely sir, because I forget "

Mrs. $H$ "That's because I forgot sir"

Mrs. A "If I was in the early stages of pregnancy, Sir, if it's rare now because I forget it, Sir, if it's sleepy at night, just sleep.

Mrs. M "I rarely do it, Sir, because it doesn't fit. Sometimes I get a headache after drinking "

Mrs. N "If I take it every 2 days, I don't have excess blood, Sir

Mrs. A "I'm routine sir"

During pregnancy, the mother's nutritional needs increase to support fetal growth and physiological changes in the mother. The results of this study indicate that there is an increase in the frequency and amount of food consumed during pregnancy, some of the reasons for eating more often are an increase in appetite, often feeling hungry. According to respondents' statements, several types of food used to increase nutritional intake are bread and snacks.

Mrs. M" No sir, just because of my
appetite"
Mrs. A "For me, the important thing is bread
because I often get hungry at
midnight. Then the snack is also
bread. Because the bread makes you full
quickly sir"

\section{Food taboo and suggestion, cultural belief influence}

The results of this study indicate that there are several types of foods that are not recommended for consumption during pregnancy, namely; Fruits such as pineapple, coconut water, durian, tape, which are not recommended for consumption in early pregnancy so as not to have a miscarriage. Some of these taboo foods are prohibitions from parents and mother-in-law (Box 18).

Box 18

Bu Y " For example, if it's still 1 month you can't eat pineapples, coconut water, that's all, Sir. At least you may not eat it because it says it will miscarry and the fetus won't be strong. Now I am 8 months pregnant so I don't have any restrictions

$\mathrm{Bu} \mathrm{H}$ "Yes because pineapples are sharp sir"

Mothers (simultaneously) "Pineapple, coconut, durian, tape sir, are prohibited by the parents, the mother-in-law sir.

While some types of food are recommended for consumption by pregnant women, some of these are; vegetables and fruits, tofu water, drinking lots of plain water, coconut water in pregnancy nearing birth. Several reasons are recommended to eat vegetables so that babies are healthy, tofu water for white babies, and lots of breast milk, coconut water so that babies are born clean (Box 19). 
Mrs. Fd:" You have to eat lots of fruits and vegetables, Sir, so that the fetus is healthy, you can say that the in-laws"

Mrs. A "Water knows sir, but I don't know what it is for"

Mothers "To be white, maybe a lot of milk, sir"

Mrs. M" Nothing sir"

$\mathrm{Bu} H$ "You have to drink lots of water, Sir, the family encourages you to stay at home, Sir"

Bu S "You have to drink coconut water, Sir. He said so that the baby was clean when he was born, I don't know sir, just like that was said"

Maternal confidence in the nutritional practices that have been carried out, the result of this study shows that some respondents are convinced of their diet and nutritional practices because they have followed the recommendations of health workers (midwives) and parents, but to find out whether nutrition practices have been implemented. Respondents stated that they were more certain by looking at the baby's weight at birth. Meanwhile, most respondents are not sure because so far they are still not consuming certain types of food, such as vegetables and fruits, so that their daily diet is not complete (Box 20).

Box 20.

Mrs. A. "Because I don't like vegetables, I'm not sure sir"

Bu Ft. "I'm not sure sir"

Mrs. M. "I am not sure because of what the lack of vegetables, lack of fruit, so not everything is complete ".

Mrs. Fd. "I'm not sure sir"

Mrs. E. "I am sure, Sir, because there are suggestions from midwives or parents, it is appropriate. So we will see after giving birth whether the child is nutritionally good and balanced, and at this time if I check my weight is appropriate ".

\section{Sources of information and nutritional}

\section{information needs}

Most of the respondents get information about nutrition and health during pregnancy from health workers, namely midwives, health centers, specialist doctors, and the surrounding community, besides that, it is also obtained from families at home. (Box 21).

Mrs. E " From midwives, specialist d and the surrounding community"

Mrs. Y. "From the midwife, Public Health center", Sir during a visit to the Public Health center

Mrs. H. "The same is true sir, from midwives, health centers, specialist doctors, housekeepers

Mrs. S, Mrs. A, Mrs. M. "The same is true sir from the Public Health center"

Only a small proportion of respondents use social media (Whatsapp, youtube, and Facebook) as a source of information about nutrition (Box 22).

\section{Mrs. Fd. "There is sir, for example, what healthy food, what can not be eaten Mrs. E. "What foods do we need to avoid so that we no longer have nausea and vomiting. Mrs. H. "If I'm not there, Sir. Most open the cellphone to call the husband ".}

The results showed that respondents needed explanations and information related to; Good nutrition for pregnancy requires a more detailed explanation. The form of information media needed is in the form of a book, and respondents stated that so far there has been a Mothers and Child Health guideline book but the nutritional information is not too detailed in it. Besides, respondents expect structured and routine nutrition education every month on nutrition during pregnancy. Respondents also stated that so far they rarely received counseling, especially regarding nutrition for pregnant women (Box 23).

The type of information required.

Box 23.

Mrs. F d. "Good nutrition for pregnancy "

Bu Ft. "Good nutrition sir" 
Mrs. Fd. " Need more details sir"

\section{The desired media form}

Mrs. Fd and Mrs. Y. "We recommend a book, sir, so we can read and read".

Mothers. "Poster $b$ is also by Sir, but the good thing is it's a book so it's easy to read and not forget "

Mrs. H. "The KIA book is not enough Sir, there is still a lack of detail. So we need something special, Sir".

\section{Expectations related to}

\section{outreach/education activities}

Mrs. E. "The hope is that if possible, often provide counseling like this Sir, about nutrition, the point is for Hamillah Sir ". Mrs. E. "If possible, once a month, sir " Mothers: Rarely Sir, if this is new nutrition. Mrs. E. "Yes sir, we do know at a glance, but if we are reminded often, we know better

Based on the above results, it can be identified about nutrition practices in pregnant women, pre-conception care of mothers before pregnancy, application of balanced nutrition and maternal diet during pregnancy, as well as factors related to nutritional practices, namely the condition of maternal knowledge, socio-cultural eating, and the information required. by mothers, both from officers and other sources of information (Table 2).

Table 2. Summary of focus group discussion results

\begin{tabular}{ll}
\hline \multicolumn{1}{c}{ Aspects } & Summary of results \\
\hline Pre- & Most pregnant women do \\
conception & not make special \\
care before & preparations for pregnancy, \\
pregnancy & such as checking their \\
& nutritional status, Hb levels \\
& to detect anemia and \\
& improving their diet to deal \\
& with pregnancy. \\
& This condition is caused by \\
& some mothers who do not \\
& specifically plan a \\
& pregnancy so that some \\
& carry out health checks \\
& after knowing that they are \\
& pregnant. Besides, pregnant \\
& women do not know what to \\
prepare before becoming
\end{tabular}

pregnant, including how to assess the nutrition status

Nutrition - Some pregnant women
knowledge already know the signs of malnutrition and symptoms and signs of anemia such as; dizziness, pallor, lethargy, pale eyelids, nausea, lack of enthusiasm, and numbness, but some pregnant women still identify anemia with blood pressure or symptoms of hypotension/low blood pressure.

- Some pregnant women also know the risk factors of pregnancy, among others; pregnant in old age, diabetics, hypertension, and poor nutrition.

- Some mothers also know the impact of malnutrition on pregnancy, namely that the mother's weight decreases and is dangerous for the fetus.

- Pregnant women generally do not know exactly how much weight gain should be during pregnancy, even though a small number have linked weight gain to be based on the mother's previous weight.

- Pregnant women generally don't understand in detail how a balanced nutrition pattern should be for pregnant women, some women identify balanced nutrition with the consumption of vegetables and fruits in foods other than carbohydrates and protein, generally pregnant women still identify balanced nutrition with Basic Four Slogan.

- Some pregnant women already know the signs of malnutrition and symptoms and signs of anemia such as; dizziness, pallor, 


\begin{tabular}{|c|c|}
\hline & 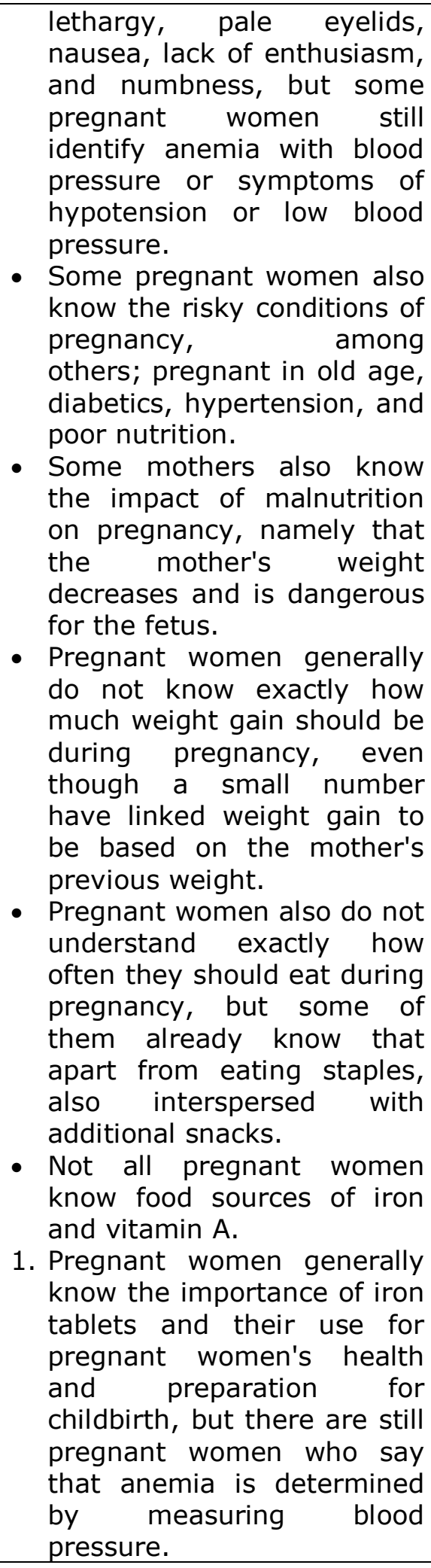 \\
\hline $\begin{array}{l}\text { Nutrition } \\
\text { practices }\end{array}$ & $\begin{array}{l}\text { - The frequency of eating for } \\
\text { pregnant women is } \\
\text { generally between } 3 \text { to } 5 \\
\text { times, the frequency of } \\
\text { eating depends on the }\end{array}$ \\
\hline
\end{tabular}

presence of hunger

- Not every meal that pregnant women apply various types of foodstuffs in a plate, most pregnant women eat rice, vegetables, and animal side dishes, but not every meal they sometimes only use rice and fish.

- The consumption pattern still emphasizes the amount (number of meals) not yet focused on the availability of at least 5 types of food ingredients

2. Most of the pregnant women already consume additional food made by themselves in the form of fruits, green bean porridge, bread, or biscuits.

Food - There are still several types
Taboos,

foods

suggestion, and cultural belief of food Taboos, that are subject to consumption, especially during early pregnancy, among others; fruits (pineapple, durian), coconut water, tape to prevent miscarriage.

- Some types of food that are suggested for consumption are vegetables and fruits, tofu water, drinking lots of water, and coconut water, especially in late pregnancy.

- The recommendation is to drink tofu water so that the baby is white and coconut water so that the baby is clean at birth

- Most of the mothers stated that they were not sure about the diet that was applied during pregnancy because they still lacked consumption of certain types of food such as vegetables and fruits, and stated that their diet was incomplete.

Sources of - Sources of information that information are used as references by and pregnant women are health 


\begin{tabular}{ll}
\hline nutritional & workers (midwives, health \\
information & workers at Public Health \\
needs & Center, specialist doctors, \\
& and local communities \\
& (family and neighbors).
\end{tabular}

- The use of information media such as social media, electronic media as a source of information on nutrition and pregnancy health is still low.

- Some Information needed by pregnant women, among others; good nutrition during pregnancy with complete and detailed information

- The information media needed is in the form of a book so that it can be read over and over again.

- Nutrition education activities are needed with frequent frequency for pregnant women.

\section{Discussion}

\section{Pre-conception care and nutrition practices before pregnant}

The results of this study (Table 2) show that most of the pregnant women do not have special readiness to face pregnancy, both from the nutritional aspects, namely examination of nutritional status and anemia status, this condition is caused by most mothers not planning a pregnancy, and do not know anything. that must be prepared to face pregnancy. The readiness of the mother before pregnancy affects the preconception of care practices that the mother uses in dealing with pregnancy. Tayden (2016) stated one of the actions preventive to improve the outcome of pregnancy is doing preconception care to know the condition before pregnancy, include; biochemical status, behavior, and social factors that can cause a high risk of pregnancy.

Several research results in various countries also show results that are almost the same as this research, the results of the study of Bortolus et al (2017) on pregnant women in Italy also show that there are several obstacles and still lack of attention to the preconception of health relating to women, health care professionals and policies. The low level of maternal attention to preconception care is influenced by various factors, including low knowledge, attitudes towards service, and examinations in the preconception phase (Bortolus et al. 2017).

Besides that, the result of a systematic review by Goossens et al. (2018) shows that some several obstacles and supporters that affect the preconception of health care by health workers, namely; less supportive attitude of officers, low knowledge of pre-conception care at the provider level, while the factors at the patient level are; not checking health workers, negative attitude, and lack of knowledge about preconception care. Another factor is the limited resources at the organizational and social levels, such as; lack of time, tools, guidelines, and reimbursement.

\section{Nutrition knowledge and nutrition practices}

The results of the study (Table 2 ) that most of the pregnant women had low knowledge of nutrition, only some mothers knew the signs of anemia, risk factors for pregnancy, and the impact of malnutrition on pregnancy outcomes, weight gain during pregnancy, balanced nutrition, and the importance of iron tablets. The low knowledge of nutrition for pregnant women can be caused by various factors, both from the mother, the role of health workers, and health service institutions, as well as social factors. Wong et al. (2018) in Malaysia show that the work of pregnant women and family income is related to the high knowledge of nutrition for pregnant women. Good nutritional knowledge will have an impact on nutritional practices. $\mathrm{H}$ acyl study Oh et al. (2019) also show that knowledge and attitudes have a very strong relationship with nutrition practices in pregnant women.

Some studies show the nutritional knowledge of pregnant women remains low. A study by Zerfu et.al in Ethiopia shows that the knowledge of pregnant women about dietary diversity practice is still lacking (poor), $47 \%$ of pregnant women do not pay attention to balanced nutrition (Zerfu et al, 2018). Another study in Pati Indonesia by Saepul et al. (2019) and Sriwahyuni, et.al 
(2020) showed the majority of pregnant women $(84.4 \%)$ had knowledge of nutrition with less category, as well as studies and Zema Nana (2018) in Ethiopia shows more than a third $(38.6 \%)$ of pregnant women have less nutritional knowledge.

Different studies have shown different results where most pregnant women already have good nutritional knowledge. The results of the Tolu Eni-Olorunda et al. (2015) in Abeokuta South Local Government Area of Ogun State shows that $75.5 \%$ of pregnant women know that malnutrition is a risk factor for pregnancy, as well as the results of the study by Wong et al. (2018) in Malaysia, showed that $63.3 \%$ of pregnant women have good knowledge of nutrition.

The results of the study (Table 2) show that the application of balanced nutrition in pregnant women is still low, which is indicated by the frequency of eating that is not according to standards, the diversity of consumption of types of food is not complete according to the diversity of food consumption standards, namely at least four types of food ingredients from different food groups, namely a source of carbohydrates, a source of non-animal protein, a source of vegetable protein, vegetables, and fruit. These results are the same as those of Tsegaye et al. (2020) in Ethiopia where many pregnant women have low nutrition practices. The study of Nana and Zema (2018) in Ethiopia also shows that $60.7 \%$ of pregnant women have poor dietary practices.

A meta-analysis study by Hidru et al. (2020) in Ethiopia showed 53\% (95\% CI: $44 \%, 62 \%$ ) pregnant women inadequate dietary diversity, several factors that influence are food security, family size greater than four, rural residence, no formal educational status, and a lack. of counseling about dietary diversity. The study of Tsegaye et al. (2020) also shows that lack of nutrition practices in pregnant women is influenced by factors of education and family economic status.

\section{Food Taboos, foods suggestion, and cultural belief}

The results of the study (Table 2) show that there are still barriers to socio-cultural effects on nutrition practices in pregnant women, this condition can be seen from the presence of taboo on certain foods in early pregnancy, several types of dietary restrictions, among others; fruits (pineapple, durian), coconut water, cassava fermented or "tape". The prohibition against food is based on public belief to prevent miscarriage, on the other hand, at the end of pregnancy, there are recommendations to consume vegetables and fruits, tofu water, drink lots of water and coconut water in the belief that it helps clean the baby clean at birth. The results of this study also showed that pregnant women were not sure about the diet they applied because they had not consumed certain types of food such as vegetables and fruits.

The results of a similar study by Darmawati et al. (2020) in Aceh shows that one of the factors related to high anemia in pregnant women is associated with cultural beliefs, namely the existence of certain traditional food taboos. The results of other studies in Madura also show that many food taboos and food suggestions are still being applied to pregnant women Madura, several types of food that are considered taboo among pregnant women, including squid, shrimp, pineapple, Kedondong, cabbage, cold water, and instant noodles. On the other hand, some of the recommended foods are rice, corn rice, skipjack tuna, tilapia fi sh, milk fish, egg, moringa leaves, apples, and coconut water (Diana et al. 2018).

Various studies in several countries also show almost the same results, as the study of Chakona and Shackleton (2019) at Eastern Café, South Africa shows $37 \%$ of pregnant women have nutrition practices that are formed from one or more practices shape by local cultural taboos or beliefs, some of the taboos practices were learned or obtained from their mothers or grandmothers. In another study by Shahid et al. (2011) there is still a strong influence on food beliefs that affect the food intake of pregnant women.

\section{Sources of information and nutritional information needs}

The results of the study (Table 2) show that most pregnant women obtain information from health workers (midwives, health workers, and specialist doctors), from the local community where they live (family and 
neighbors), meanwhile the use of social media and media electronics as a source of nutritional information is still small. Research results have also shown the majority of pregnant women states require a source of information in book form with the contents of the message easy to understand, so it can be read again and again sat needed, but it requires a structured education with greater frequency by health care workers or others.

Several studies on pregnant women also show that the main source of information is obtained from health workers, the results of the study of Bortolus et al (2017) in Italy show that the main source of information from pregnant women is health personnel, namely obstetric-gynecologists. The results of the study by Scewejcer et al. (2008) show a different matter where the most favorite information media used by pregnant women apart from the pocketbook for pregnant women is the Internet.

Basically, during pregnancy, pregnant women need to be provided with various information related to pregnancy, according to the study of Kamali et al. (2018) partially expectant mothers information need about baby care, physical and psychological complication after birth, fetal growth and development, nutrition dive pregnant, and special examinations during pregnancy, however general, pregnant women need the information when they are experiencing illness or complications pregnancy. Another study by Almalik and Mosleh (2017) shows that pregnant women need a high degree of importance of specific learning topics that are closely relevant to their current period of pregnancy.

The need for pregnant women for information is influenced by many factors, the results of the study by Sharifi et al. (2020) in Iran shows that information needs during pregnancy are influenced by age, education level, husband's education level, length of stay and place of residence, number of children and previously obtained information, and routine prenatal care. The results of the study by Ferraro et al. (2011) most pregnant women do not get sufficient information about the specific needs of energy and nutrients to support the gestational weight gain target, most pregnant women get various information and get information from care providers. Sources of information are an important factor in the effort to deliver the various services and practices that mothers must do, both before, during pregnancy, and after delivery. The provision of information can be done through electronic media and social media, books, and other printed media such as posters, leaflets, and booklets, as well as through direct delivery by officers both in health services and in the community.

\section{Conclussions and Sugestions}

Most of the pregnant women did not get and done pre-conception nutrition care, had insufficient nutritional knowledge and the nutrition practices among pregnant was still low. There is still an influence of cultural belief in the form of food taboos and food suggestions, and the lack of sources of information and nutritional information towards nutrition practice. It is necessary to develop media and nutrition educational methods to improve nutrition and health care during pre-conception and pregnancy, and further studies are needed specifically on the role of family factors, especially grandmothers, mother in-laws, and family members on nutrition practices in pregnant women.

\section{Acknowledment}

This research was supported by Health Polytechnic of Aceh, we thank all enumerators from Nutrition and Dietetic Study Program Health polytechnic of Aceh and all field supervisor form Puskesmas Darul Imarah and Puskesmas Lampisang, Aceh Besar District. The authors have no conflict of interest.

\section{References}

Abu-Saad. K and Fraser D. Maternal Nutrition and Birth Outcomes. Epidemiologic Reviews; Vol. 32, 2010. DOI: 10.1093/epirev/mxq001

Almalik MMA, Mosleh SM. Pregnant women: What do they need to know during pregnancy? A descriptive study. Women Birth. 2017 Apr;30(2):100-106. doi: 10.1016/j.wombi.2016.09.001. Epub 2016 Sep 22. PMID: 27666169. 
Badan Penelitian dan Pengembangan Kesehatan RI. 2014. Buku Studi Diet Total: Survei Konsumsi Makanan Individu Indonesia 2014. Jakarta (ID). Balitbangkes RI.

Badan Penelitian dan Pengembangan Kesehatan RI. 2007. Laporan Riset Kesehatan Dasar tahun 2007. Jakarta (ID) Balitbangkes Kemenkes RI.

Badan Penelitian dan Pengembangan Kesehatan RI. 2010. Laporan Riset Kesehatan Dasar tahun 2010. Jakarta (ID). Balitbangkes Kemenkes RI.

Badan Penelitian dan Pengembangan Kesehatan RI. 2013. Laporan Riset Kesehatan Dasar tahun 2013. Jakarta (ID). Balitbangkes Kemenkes RI.

Bortolus R, Oprandi NC, Rech Morassutti F, Marchetto L, Filippini F, Agricola E, Tozzi $A E$, Castellani C, Lalatta F, Rusticali B, Mastroiacovo P. Why women do not ask for information on preconception health? A qualitative study. BMC Pregnancy Childbirth. 2017 Jan 5;17(1):5. doi: 10.1186/s12884-016-1198-z. PMID: 28056865 ; PMCID: PMC5217233.

Darmawati, Tongku N. Siregar, Hajjul Kamil, Teuku Tahlil, "Acehnese Cultural Leaders' Perspective on Anemia in Pregnant Women: A Qualitative Study", Advances in Public Health, vol. 2020, Article ID 8710254, 6 pages, 2020. https://doi. org/10.1155/2020/8710254

Diana. R, Kusuma. R, Rachmayanti. RD, Anwar. F, Khomsan. A, Christianti. DF, Food taboos, and suggestions among Madurese pregnant women: a qualitative study. Journal of Ethnic Foods 2018; 5: $246 \mathrm{e} 253$.

Eni-Olorunda. T, Akinbode. OO, Akinbode. AO, Knowledge, and Attitude of Mothers on risk factors influencing pregnancy outcomes in Abeokuta South Local Government Area, Ogun State. European Scientific Journal April 2015 edition vol.11, No.11 ISSN: 1857 - 7881 (Print) e - ISSN 1857- 7431
Ferraro. ZM, Rhutenford. J, Keely. EJ, Dubois. L, Adamo. KB (2011). An assessment of patient information channels and knowledge of physical activity and nutrition during pregnancy. Obstetric Medicine 4(2):59-65

DOI: $10.1258 /$ om.2011.110006

Goossens J, De Roose M, Van Hecke A, Goemaes R, Verhaeghe S, Beeckman D. Barriers and facilitators to the provision of preconception care by healthcare providers: A systematic review. Int J Nurs Stud. 2018 Nov;87:113-130. doi: 10.1016/j.ijnurstu.2018.06.009. Epub 2018 Jun 18. PMID: 30096578.

Gamuchirai Chakona. G and Shackleton, C. Food Taboos and Cultural Beliefs Influence Food Choice and Dietary Preferences among Pregnant Women in the Eastern Cape, South Africa. Nutrients 2019, 11, 2668; doi: $10.3390 /$ nu11112668.

Hidru. HD, Berwo Mengesha M, Hailesilassie $Y$, Tekulu Welay F. Burden and Determinant of Inadequate Dietary Diversity among Pregnant Women in Ethiopia: A Systematic Review and Meta-Analysis. $J$ Nutr Metab. 2020;2020:1272393. Published $2020 \quad$ Aug 14. doi: $10.1155 / 2020 / 1272393$.

Kamali S, Ahmadian L, Khajouei R, Bahaadinbeigy $K$. Health information needs of pregnant women: information sources, motives, and barriers. Health Info Libr J. 2018 Mar;35(1):24-37. doi: 10.1111/hir.12200. Epub 2017 Nov 13. PMID: 29131537.

Madanijah, S. et al. Nutritional status of prepregnant and pregnant women residing in Bogor district, Indonesia: a crosssectional dietary and nutrient intake study. Br. J. Nutr. 116, S57-66 (2016).

Nana A, Zema T. Dietary practices and associated factors during pregnancy in northwestern Ethiopia. BMC Pregnancy Childbirth. 2018;18(1):183. Published 2018 May 25. doi:10.1186/s12884-0181822-1 
Oh H-K, Kang S, Cho S-H, Ju Y-j, Faye D (2019) Factors influencing nutritional practices among mothers in Dakar, Senegal. PLoS ONE 14(2): e0211787. https://doi.org/10.1371/journal.pone.02 $\underline{11787}$

Saepul, S., Hermayanti, Y., and Platini, H. (2019). Knowledge About Nutritional Intake in Pregnant Women with Anemia. Jurrnal Pendidikan Keperawatan Indonesia 5(2), p. 114-123. Doi:10.17509/jpki.v5i2.18706.

Shahid A, Ahmed M, Rashid F, Khan MW, Mahmood-ur Rehman. Women's beliefs \& practices regarding food during pregnancy - a hospital-based study. Professional Med J Apr-Jun 2011;18(2): 189-194

Sharifi M, Amiri-Farahani L, Haghani S, Hasanpoor-Azghady SB. Information Needs During Pregnancy and Its Associated Factors in Afghan Pregnant Migrant Women in Iran. J Prim Care Community Health. 2020 JanDec;11:2150132720905949. doi: 10.1177/2150132720905949. PMID: 32070182; PMCID: PMC7031785.
Sriwahyuni, S., Marniati, Putri, E. S., \& Husna, A. (2020). The effects of mother's knowledge and husband's support on childbirth assistance by a traditional birth attendant. International Journal of Psychosocial Rehabilitation, 24(6), 33173324.

Szewejcer EM, Hiddink. GJ, Maas. L, Koelen M, (2011). Nutrition-related informationseeking behaviors of women trying to conceive and pregnant women: Evidence for the life course perspective. Family Practice 25 Suppl 1(Supplement 1):i99104. DOI: $10.1093 /$ fampra/cmn077

Tsegaye D, Tamiru D, Belachew T. Factors Associated with Dietary Practice and Nutritional Status of Pregnant Women in Rural Communities of Illu Aba Bor Zone, Southwest Ethiopia. Nutrition and Dietary Supplements. 2020;12:103-112 https://doi.org/10.2147/NDS.S257610.

Tyden T (2016). Why is preconception health and care important?. UPSALA JOURNAL OF MEDICAL SCIENCES, 2016 VOL. 121, NO. 4, 207. http://dx.doi.org/10.1080/03009734.20 $\underline{16.1211776}$ 